\title{
Perbedaan Pandangan Ajaran Sifat Melawan \\ Hukum Materiil Tindak Pidana Korupsi
}

\author{
Seno Wibowo,* Ratna Nurhayati**
}

\begin{abstract}
Abstrak
Penerapan ajaran sifat melawan hukum materiil dalam fungsi positif dalam Undang-Undang Nomor 20 Tahun 2001 tentang Perubahan Atas Undang-Undang Nomor 31 Tahun 1999 tentang Pemberantasan Tindak Pidana Korupsi (UU Tipikor 2001) oleh Mahkamah Agung pasca putusan Mahkamah Konstitusi telah bertentangan dengan Undang-Undang Dasar 1945 Pasal 28 ayat (1) huruf D dan asas legalitas serta asas pemisahan kekuasaan negara. Selain itu, hal tersebut juga dinilai tidak mengindahkan sudut hierarki peraturan perundangundangan di Indonesia, sehingga tidak mencerminkan kepastian hukum. Mahkamah Agung tidak berwenang menerapkan kembali ajaran sifat melawan hukum dalam fungsi positif yang terdapat dalam UU Tipikor 2001 dikarenakan dengan hal tersebut dinyatakan tidak memiliki kekuatan hukum mengikat oleh Mahkamah Konstitusi. Putusan judicial review Mahkamah Konstitusi tidak hanya mengikat para pihak yang berperkara namun juga rakyat dan lembaga tinggi negara termasuk Mahkamah Agung. Mahkamah Agung harus melaksanakan dan mematuhi putusan judicial review tersebut mengingat kedudukan putusan Mahkamah Konstitusi sebagai negative legislation. Apabila instansi penegak hukum maupun aparaturnya menggunakan suatu instrumen hukum yang telah dinyatakan tidak mempunyai kekuatan mengikat secara hukum, maka akibat hukum yang terjadi dapat berupa kerugian finansial. Instansi penegak hukum atau aparaturnya dapat menanggung akibat hukum secara pribadi (personal liability) untuk mengganti kerugian yang dituntut melalui peradilan biasa yang ditegakkan secara paksa dan demi hukum batal sejak semula (ab initio).
\end{abstract}

Kata Kunci: ajaran sifat melawan hukum materiil, judicial review, Mahkamah Agung, Mahkamah Konstitusi, negative legislation.

\section{The Different Perspectives the Nature of Unlawful Material Doctrine of Corruption}

\begin{abstract}
The application of the unlawful material doctrine in a positive function in Law Number 20 in 2001 on The Amendment of Law Number 31 in 1999 on Corruption Eradication (UU Tipikor 2001) by the Supreme Court after the decision of the Constitutional Courts contrary to the Constitution of 1945 Article 28 D paragraph 1 and the principle of legality and separation of

PADJADJARAN Jurnal IImu Hukum Volume 2 Nomor 2 Tahun 2015 [ISSN 2460-1543] [e-ISSN 2442-9325]

* Dosen Universitas Terbuka, Jalan Cabe Raya, Pondok Cabe-Pamulang, Tangerang Selatan, seno@ut.ac.id, S.H., M.H. (Universitas Sebelas Maret).

**Dosen Universitas Terbuka, Jalan Cabe Raya, Pondok Cabe-Pamulang, Tangerang Selatan, anna@ut.ac.id, S.H. (Universitas Diponegoro), M.Hum. (Universitas Gadjah Mada).
\end{abstract}


state powers. The application does not heed the hierarchy of legislation in Indonesia, and thus does not reflect any legal certainty. The Supreme Court has no authority to reimplement the unlawful materiel doctrine in the positive functions contained in the law of corruption in this case, because it is adjudged in the judicial review by Constitutional Court which has no binding force. The decision by the Constitutional Court for a judicial review binds the litigants as well as the citizen and state officials. The Supreme Court should also implement and abide by the decision of the judicial review with consideration that the Constitutional Court's decision is a negative legislation. If a law enforcement agency or apparatus uses a legal instrument which has been declared having no legal binding, legal consequences are to occur in the form of financial losses to the extent that the state officials shall be liabileto give compensation, which, through the regular court, can be enforced by force and by the void from the beginning law (ab initio).

Keywords: unlawful material doctrine, judicial review, Supreme Court, Supreme Constitutional Court, negative legislation.

\section{A. Pendahuluan}

Korupsi merupakan suatu kejahatan yang sangat menimbulkan keprihatinan masyarakat dunia maupun rakyat Indonesia pada khususnya. Keprihatinan masyarakat internasional tercermin pada bagian pembukaan Konvensi Perserikatan Bangsa-Bangsa (PBB) Anti Korupsi 2003 atau United Nations Convention Against Corruption (Konvensi PBB 2003) yang menyatakan korupsi dapat mengancam dan menimbulkan masalah terhadap stabilitas dan keamanan masyarakat yang melemahkan lembaga-lembaga dan nilai-nilai demokrasi, etika, dan keadilan, serta membahayakan pembangunan berkelanjutan dan supremasi hukum. Dengan demikian, diperlukan suatu pendekatan komprehensif dan multidisipliner untuk mencegah dan memerangi korupsi secara efektif. ${ }^{1}$

Reaksi dan keprihatinan masyarakat di Indonesia muncul dengan tumbangnya rezim orde baru dan lahirnya atau dimulainya rezim reformasi di Indonesia. Pada era reformasi, semangat penanggulangan korupsi dilakukan dengan beberapa langkah atau upaya, yakni dengan berlakunya produk perundang-undangan seperti Ketetapan Majelis Perwakilan Rakyat (Tap MPR) Nomor XI/MPR/1998, UndangUndang Nomor 28 Tahun 1999 tentang Penyelenggaraan Negara Yang Bersih Dari Korupsi Kolusi Dan Nepotisme (UU KKN 1999), Undang-Undang Nomor 20 Tahun 2001 tentang Perubahan Atas Undang-Undang Nomor 31 Tahun 1999 tentang Pemberantasan Tindak Pidana Korupsi (UU Tipikor 2001), dan Undang-Undang Ratifikasi Konvensi PBB 2003 melalui Undang-Undang Nomor 7 Tahun 2006.

1 Elwi Danil, Korupsi, Konsep, Tindak Pidana, Dan Pemberantasannya, Jakarta: Rajawali Press, 2011, hlm. 64. 
Selain itu, pada era reformasi juga telah lahir lembaga-lembaga negara yang menunjang penegakan hukum dalam penanggulangan korupsi yang diatur dalam Undang-Undang Dasar 1945 (UUD 1945) seperti Komisi Yudisial (KY), Mahkamah Konstitusi (MK), dan Komisi Pemberantasan Korupsi (KPK). Adanya lembagalembaga negara tersebut diharapkan tercipta sistem peradilan terpadu, baik di bidang hukum privat maupun hukum publik. Sebagai contoh, pada sistem peradilan pidana terdapat koordinasi dan supervisi atas proses penyelidikan dan penyidikan serta penuntutan terhadap tindak pidana korupsi antara KPK yang menjadi supervisi lembaga Kepolisian Republik Indonesia (Polri) dan Kejaksaan. Sedangkan pada proses pemeriksaan di pengadilan dilakukan oleh Mahkamah Agung (MA).

Sebagaimana diketahui, saat ini Indonesia memiliki dua lembaga yudisial yang melaksanakan kekuasaan kehakiman, yaitu MA dan MK. Kedua kekuasaan kehakiman tersebut dipisahkan karena pada hakikatnya lembaga tersebut memang berbeda. MA lebih merupakan pengadilan keadilan (court of justice), sedangkan MK lebih berkenaan dengan lembaga pengadilan hukum (court of law). ${ }^{2}$ Lahirnya MK diatur dalam Pasal 24 ayat (2) amandemen UUD 1945 yang berbunyi sebagai berikut:

"Kekuasaan kehakiman dilakukan oleh sebuah Mahkamah Agung dan badan yang berada di bawahnya dalam lingkungan peradilan umum, lingkungan peradilan agama, lingkungan peradilan militer, lingkungan peradilan tata usaha negara, dan oleh sebuah Mahkamah Konstitusi."

Adanya pemisahan lembaga tinggi antara MA dengan MK sudah tentu memiliki konsekuensi permasalahan dalam pelaksanaan peradilannya, seperti yang terjadi saat ini yakni perihal putusan judicial review MK Nomor 003/PPU-IV/2006 tertanggal 25 Juli 2006. Pada putusan tersebut dinyatakan bahwa Pasal 2 (1) UU Tipikor 2001 tidak mempunyai kekuatan hukum mengikat dan walaupun demikian MA tetap menganut ajaran sifat melawan hukum materil dalam fungsi positif. Hal tersebut dapat dilihat dari majelis hakim MA yang tetap menggunakan ajaran sifat melawan hukum materil dalam fungsi positif dengan argumentasi sebagai berikut, "Bahwa putusan Mahkamah Konstitusi RI No. 003/PPU-IV/2006 tertanggal 25 Juli 2006 yang menyatakan penjelasan Pasal 2 ayat (1) Undang-undang Tindak Pidana Korupsi dinyatakan tidak mempunyai kekuatan hukum mengikat sehingga unsur melawan hukum tersebut menjadi tidak jelas rumusannya". ${ }^{3}$ Dengan demikian, berdasarkan doktrin Sen-Clair atau La doctrine du Sen-Clair, hakim harus melakukan penemuan hukum.

2 Ni'matul Huda, Hukum Tata Negara Indonesia, Jakarta: Rajawali Press, 2007, hlm. 202.

3 Lilik Mulyadi, Tindak Pidana Korupsi Di Indonesia, Normatif, Teoritis, Praktik dan Masalahnya, Bandung: Alumni, 2007, hlm. 86. 
Dengan adanya dua pandangan yang terjadi pada kedua lembaga tinggi yang melaksanakan kekuasaan kehakiman tersebut, sudah tentu timbul permasalahan yuridis dalam penerapan UU Tipikor 2001. Hal tersebut akan menimbulkan pertentangan antar asas-asas hukum pidana dan juga dapat menimbulkan ketidakpastian hukum dalam penerapannya yang berakibat melanggar hak asasi manusia terdakwa. Selain itu juga akan berimbas pada penegakan hukum dalam pemberantasan korupsi.

Berdasarkan latar belakang di atas maka permasalahan yang dikaji dalam tulisan ini adalah mengenai pencerminan kepastian hukum atas penerapan ajaran sifat melawan hukum materiil dalam fungsi positif oleh MA pasca putusan MK dan kewenangan MA untuk menerapkan kembali ajaran sifat melawan hukum materiil dalam fungsi positif tersebut.

\section{B. Kajian Penerapan Ajaran Sifat Melawan Hukum Materiil dalam Fungsi Positif Oleh MA Pasca Putusan MK dari Segi Kepastian Hukum}

Terdapat 4 bentuk kategorisasi melawan hukum dalam perspektif ilmu pengetahuan hukum pidana. Pertama, sifat melawan hukum umum yang diartikan sebagai syarat untuk dapat dipidananya suatu perbuatan sebagaimana rumusan pengertian tindak pidana. Kedua, sifat melawan hukum khusus atau sifat melawan hukum faset lazim terdapat dalam rumusan tindak pidana anasir melawan hukum dicantumkan secara tegas dalam rumusan pasal yang bersangkutan sehingga sifat melawan hukum ini merupakan syarat tertulis untuk dapat dipidananya suatu perbuatan. Ketiga, sifat melawan hukum formal diartikan sebagai semua unsurunsur delik telah terpenuhi oleh perbuatan yang dilakukan pelaku tindak pidana. D. Schaffmeister memberi contoh sifat melawan hukum formal dalam peradilan Indonesia, yakni dalam putusan MA Nomor 30/K/Kr/1969 tertanggal 6 Juni 1970. Dalam kasus tersebut, seseorang diadili berdasarkan tuduhan penadahan yang diatur dalam Pasal 480 Kitab Undang-Undang Hukum Pidana (KUHP), yaitu melalui tindakan membeli skuter yang berasal dari kejahatan. Terdakwa membeli di pasar dan menyatakan bahwa suratnya beres namun ketika terdakwa membaca di koran tentang asal usul skuter tersebut maka terdakwa dengan segera melapor ke kepolisian. Dinyatakan dalam putusan bahwa tidak ada sifat melawan hukum dari perbuatan terdakwa. Tampaknya yang dimaksud ialah tidak terpenuhinya persyaratan utama perbuatan melawan hukum formal sebagai unsur tertulis dari perumusan delik 480 KUHP sehingga tidak terdapat perumusan unsur dolus maupun culpa.

Keempat, sifat melawan hukum materiil baik fungsi positif maupun negatif. Sifat melawan hukum materiil dalam fungsi positif diartikan meskipun perbuatan tersebut tidak diatur dalam peraturan perundang-undangan, namun jika perbuatan 
tersebut dianggap tercela karena tidak sesuai dengan rasa keadilan atau normanorma keadilan atau norma-norma kehidupan sosial masyarakat, maka perbuatan tersebut dapat dipidana. Sifat melawan hukum materiil dalam arti negatif dimaksudkan meskipun perbuatan telah memenuhi unsur delik, akan tetapi perbuatan tersebut tidak bertentangan dengan rasa keadilan masyarakat, maka perbuatan tersebut tidak dapat dipidana. ${ }^{4}$

Berdasarkan penjabaran di atas, maka dapat diketahui bahwa sifat melawan hukum marteriil dalam fungsi positif di Indonesia terdapat dalam Penjelasan Pasal 2 ayat (1) UU Tipikor yang berbunyi:

“Yang dimaksud dengan 'secara melawan hukum' dalam Pasal ini mencakup perbuatan melawan hukum dalam arti formil maupun dalam arti materiil, yakni meskipun perbuatan tersebut tidak diatur dalam peraturan perudang-undangan, namun apabila perbuatan tersebut dianggap tercela karena tidak sesuai dengan rasa keadilan atau norma-norma kehidupan sosial dalam masyarakat, maka perbuatan tersebut dapat dipidana...."

Jika diperhatikan, kembali dari penjelasan tersebut, maka dapat dikatakan bahwa suatu perbuatan korupsi itu dapat dipidana tidak hanya berdasarkan ketentuan hukum pidana tertulis tetapi juga pada hukum tidak tertulis berdasarkan rasa keadilan atau norma yang ada di masyarakat. Hal ini tentu mengakibatkan para ahli hukum pidana memiliki perbedaan pendapat mengenai relevansi ajaran sifat melawan hukum materiil dalam fungsi positif ini.

Jika diperhatikan, penerapan ajaran sifat melawan hukum materiil di Indonesia sendiri oleh MA, baik sebelum maupun sesudah dibentuk dan diberlakukan UU Tipikor 2001, telah menerapkan 2 ajaran sifat melawan hukum materiil, baik dalam fungsi positif maupun dalam fungsi negatif. Contoh penerapan ajaran sifat melawan hukum materiil dalam fungsi negatif oleh MA pada putusan perkara tindak pidana korupsi atas nama Machrus Effendi tertanggal 8 Januari 1966, Reg. Nomor 42 K/Kr/1965 dan perkara tindak pidana korupsi atas nama Ir. Otjo Danuatmadja tertanggal 20 Maret 1977, Reg. Nomor 81 K/ Kr/1973.

Sedangkan di sisi lain, MA juga telah menerapkan ajaran sifat melawan hukum materiil dalam fungsi positif pada perkara tindak pidana korupsi atas nama terdakwa Drs. R. S Natalegawa pada putusan Nomor 275 K/Pid/1983 tanggal 29 Desember $1983^{5}$, dan pada kasus pemberian kredit oleh Bank Mandiri yaitu E.C.W Neloe walaupun telah ada putusan judicial review MK pada saat pemeriksaan berlangsung. ${ }^{6}$ Dengan demikian, MA sendiri tampaknya agak ragu dan tidak

4 Lilik Mulyadi, Bunga Rampai Hukum Pidana Umum dan Khusus, Bandung: Alumni, 2012, hlm. 23.

5 Lilik Mulyadi, Tindak Pidana Korupsi......, Op.Cit., hlm. 84.

6 Lihat Jonker Sihombing, Tanggung Jawab Yuridis Bankir Atas Kredit Macet Nasabah, Bandung: Alumni, 2009, hlm. 122. 
konsisten dalam menetapkan paradigma penerapan ajaran sifat melawan hukum materiil. Hal ini dapat menimbulkan ketidakpastian hukum dan MK sendiri telah menyatakan bahwa Penjelasan Pasal 2 ayat (1) UU Tipikor 2001 dinyatakan tidak memiliki kekuatan hukum mengikat dengan berbagai aspeknya baik dari kepastian hukum dan asas hukum pidana fundamental lainnya.

Dalam UUD 1945 pada Pasal 28 ayat (1) huruf D disebutkan bahwa, "Setiap orang berhak atas pengakuan, jaminan, perlindungan dan kepastian hukum yang adil serta perlakuan yang sama di hadapan hukum". Ketentuan tersebut mengindikasikan negara Indonesia melindungi warga negaranya sehingga dengan adanya frasa, "kepastian hukum yang adil maka sudah tentu ajaran sifat melawan hukum materiil dalam fungsi positif bertentangan dengan Pasal 28 ayat (1) huruf $D$ amandemen UUD 1945". Pertentangan ini juga telah dinyatakan dalam salah satu pertimbangan MK melalui putusan Nomor 003/PPU-IV/2006 tertanggal 25 Juli 2006 atas judicial review Penjelasan Pasal 2 ayat (1) UU Tipikor 2001 yang menyatakan sebagai berikut, "ajaran melawan hukum materiil fungsi positif tersebut telah bertentangan dengan hak konstitusional rakyat Indonesia karena tidak mencerminkan adanya jaminan kepastian hukumnya." Pertimbangan MK lainnya adalah bahwa asas legalitas dalam Pasal 1 ayat (1) KUHP menuntut asas kepastian hukum dimana orang dapat dituntut dan diadili atas dasar suatu perundangundangan yang tertulis (lex scripta) yang telah lebih dulu ada. ${ }^{7}$

Moeljatno menyatakan bahwa asas legalitas, yang istilah latinnya nullum delictum, nulla poena sine praevia legi poenali (tiada suatu perbuatan yang dapat dipidana, selain berdasarkan kekuatan ketentuan perundang-undangan pidana yang mendahuluinya), mengandung tiga pengertian, yaitu: ${ }^{8}$

1) Tidak ada perbuatan yang dilarang dan diancam dengan pidana kalau hal itu terlebih dahulu belum dinyatakan dalam suatu aturan undang-undang;

2) Untuk menentukan adanya perbuatan pidana tidak boleh menggunakan analogi; dan

3) Aturan aturan hukum pidana tidak berlaku surut.

Sementara itu, menurut Groenhuijsen seperti yang dikutip oleh Komariah Emong Sapardjaja, ada empat makna yang terkandung dalam asas ini. Dua dari yang pertama ditujukan kepada pembuat undang-undang dan dua yang lainnya merupakan pedoman bagi hakim. Pertama, pembuat undang-undang tidak boleh memberlakukan suatu ketentuan pidana yang berlaku mundur. Kedua, semua perbuatan yang dilarang harus dimuat dalam rumusan delik yang sejelas-jelasnya.

\footnotetext{
7 Chaerudin, Syaiful Ahmad Dinar, Syarif Fadilla, Strategi Pencegahan \& Penegakan Hukum Tindak Pidana Korupsi, Bandung: Refika Aditama, 2008, hlm. 10.

8 Moeljatno, Asas Asas Hukum Pidana, Jakarta: Bina Aksara, 1987, hlm. 25.
} 
Ketiga, hakim dilarang menyatakan bahwa terdakwa melakukan perbuatan pidana didasarkan pada hukum tidak tertulis atau hukum kebiasaan. Keempat, terhadap aturan hukum pidana dilarang penerapan analogi. ${ }^{9}$ Demikian pula menurut Richard G Singer dan Martin R. Garner yang dikutip oleh Eddy O.S. Hiariej, yang menyatakan bahwa ada tiga aspek yang berkaitan dengan asas legalitas. Pertama, tidak dapat diberlakukan rektroaktif. Kedua, pembentuk undang-undang dilarang membuat hukum yang berlaku surut. Ketiga, perbuatan hukum pidana harus didefinisikan oleh lembaga atau institusi yang berwenang. ${ }^{10}$

UU Tipikor 2001 menganut ajaran sifat melawan hukum materiil dalam fungsi positif, yang mana dalam menentukan perbuatan pidana meskipun perbuatan tersebut tidak diatur dalam peraturan perundang-undangan, namun jika perbuatan tersebut dianggap tercela karena tidak sesuai dengan rasa keadilan atau normanorma keadilan atau norma-norma kehidupan sosial masyarakat, maka perbuatan tersebut dapat dipidana. Hal ini tentu saja kontradiktif atau bertentangan dengan asas legalitas hukum pidana sebagaimana telah dijabarkan oleh Moeljatno di atas.

Asas legalitas dalam hukum pidana materiil merupakan asas yang paling fundamental dan mengandung unsur perlindungan dikarenakan sanksi pidana merupakan sanksi yang dipandang lebih berat daripada sanksi atau hukuman di bidang hukum lain. ${ }^{11} \mathrm{Hal}$ tersebut juga untuk mencegah kesewenang-wenangan penguasa atau pemerintah, sehingga diperlukan pembatasan kewenangan penguasa melalui perundang-undangan atau hukum tertulis. Bahkan, menurut Muladi sebagaimana yang dikutip oleh Nyoman Sarikat Putra Jaya, tujuan dari asas legalitas itu adalah sebagai berikut: ${ }^{12}$

1) Memperkuat kepastian hukum;

2) Menciptakan keadilan dan kejujuran terdakwa;

3) Mengefektifkan fungsi pencegahan (deterrent function) dari sanksi pidana;

4) Mencegah penyalahgunaan kekuasaan; dan

5) Memperkokoh penerapan rule of law.

Ajaran sifat melawan hukum materiil dalam fungsi positif tersebut dapat memberikan peluang terjadinya tindakan kesewenang-wenangan, karena dalam menentukan ada tidaknya perbuatan atau tindak pidana selain ditentukan oleh hukum pidana tertulis juga berdasarkan rasa keadilan atau norma-norma keadilan

9 Komariah Emong Sapardjaja, Ajaran Sifat Melawan Hukum Materiil Dalam Hukum Pidana Indonesia (Studi Kasus Tentang Penerapan dan Perkembangannya dalam Yurisprudensi), Bandung: Alumni, 2002, hlm. 5-6.

10 Eddy O.S. Hiariej, Asas Legalitas dan Penemuan Hukum Dalam Hukum Pidana, Jakarta: Erlangga, 2009, hlm. 25-26.

11 Mompang L. Pangabean, “Kebijakan Legislatif Dalam Hukum Pelaksanaan Pidana Di Indonesia”, MasalahMasalah Hukum, Jilid 41, No 2, April 2012, hlm. 189.

12 Nyoman Sarikat Putra Jaya, Beberapa Pemikiran Ke Arah Pengembangan Hukum Pidana, Bandung: Citra Adiya Bakti, 2008, hlm. 14. 
atau norma-norma kehidupan sosial masyarakat. Selain itu, perlu diperhatikan pula bahwa Indonesia merupakan bangsa majemuk yang terdiri dari berbagai suku bangsa dan adat istiadat serta hukum adat yang berbeda antara satu dengan yang lain, sehingga apabila diterapkan ajaran sifat melawan hukum materiil dalam fungsi positif tersebut tentunya dapat memicu disparitas hukum pidana. Disparitas dalam pidana dimulai dari hukumnya sendiri' ${ }^{13}$ yang akan menimbulkan ketidakadilan dalam penerapannya dan selanjutnya akan menghilangkan kepercayaan masyarakat terhadap hukum.

Suatu perbuatan dianggap tercela karena tidak sesuai dengan rasa keadilan atau norma-norma keadilan atau norma-norma kehidupan sosial masyarakat dalam hukum pidana. Andi Hamzah menyatakan bahwa untuk menentukan pengertian 'bertentangan dengan norma-norma yang hidup di dalam pergaulan masyarakat' maka harus dilakukan penelitian terlebih dahulu; seperti bagaimana pendapat alim ulama, kepala adat, dan seterusnya, mengenai patut tidak patutnya suatu perbuatan yang dipandang melawan hukum materiil tersebut. Pendapat Andi Hamzah ini telah dinyatakan dan menjadi pertimbangan MK dalam putusan judicial review Nomor 003/PPU-IV/2006 yang berbunyi:

"Merujuk pada hukum tidak tertulis dalam ukuran kepatutan, kehatihatian, dan kecermatan yang hidup di dalam masyarakat, sebagai suatu norma keadilan adalah merupakan ukuran yang tidak pasti, dan berbedabeda dari satu lingkungan masyarakat tertentu ke lingkungan masyarakat lainnya. Sehingga apa yang melawan hukum di satu tempat mungkin di tempat lain diterima dan diakui sebagai sesuatu yang sah dan tidak melawan hukum menurut ukuran yang dikenal dalam kehidupan masyarakat setempat, sebagaimana yang disampaikan saksi ahli Andi Hamzah dalam persidangan." 14

Penulis setuju dengan pertimbangan tersebut, karena dalam merumuskan suatu formulasi ketentuan dalam hukum pidana guna menyatakan suatu perbuatan merupakan tindak pidana harus melalui penelitian terlebih dahulu.

Sifat melawan hukum materiil dalam fungsi positif merupakan perluasan norma menurut Remmelink. Hal tersebut merupakan perluasan lingkup hukum pidana sehingga lebih banyak perbuatan yang tidak disebutkan di dalam undang-undang yang dapat dinyatakan sebagai delik. Meskipun begitu, akan muncul banyak keberatan dari segi sudut pandang negara hukum. Andi Hamzah menyetujui pernyataan tersebut karena menurut beliau, penerapan melawan hukum materiil dalam fungsi positif akan membahayakan tertib hukum, bahkan dapat terjadi

\footnotetext{
13 Muladi dan Barda Nawawi Arief, Teori-teori dan Kebijakan Hukum Pidana, Bandung: Alumni, 2010, hlm. 56.

${ }^{14}$ Chaerudin, Syaiful Ahmad Dinar, Syarif Fadilla, Op.cit., hlm. 11.
} 
kesewenang-wenangan hukum. ${ }^{15}$ Sedangkan menurut pandangan Eddy O.S. Hiariej, ajaran melawan hukum materiil dalam fungsi positif bertentangan dengan asas legalitas dan oleh karenanya beliau tidak dapat menerimanya karena akan menimbulkan ketidakpastian hukum. ${ }^{16}$

Selain bertentangan dengan asas legalitas, beliau juga mengemukakan bahwa kiranya hal ini bertentangan dengan prinsip fundamental dalam hukum pembuktian pidana yang berbunyi, actori incubit onus probandi, actore non probante, reus absolvitur. ${ }^{17}$ Artinya, barang siapa yang menuntut dialah yang wajib membuktikan, jika tidak dapat dibuktikan, terdakwa harus dibebaskan. Tegasnya, jika penuntut umum dalam perkara pidana tidak dapat membuktikan unsur-unsur delik yang didakwakan kepada terdakwa (actore non probante), maka terdakwa harus diputus bebas (reus absolvitur).

Kembali kepada MA yang tetap menerapkan ajaran sifat melawan hukum materiil dalam fungsi positif pasca putusan judicial review oleh MK dengan mempertimbangkan aspek bahwa putusan MK Nomor 003/PPU-IV/2006 tanggal 25 Juli 2006 yang menyatakan penjelasan Pasal 2 ayat (1) UU Tipikor 2001 dinyatakan bertentangan dengan UUD 1945 dan telah dinyatakan tidak mempunyai kekuatan hukum mengikat dengan demikian unsur melawan hukum tersebut menjadi tidak jelas rumusannya, oleh karena itu berdasarkan doktrin Sen-Clair atau La doctrine du Sen-Clair hakim harus melakukan penemuan hukum. Penemuan hukum yang dilakukan oleh majelis hakim kasasi MA tersebut secara substansial berorientasi kepada ketentuan Pasal 5 ayat (1) Undang-Undang Nomor 48 Tahun 2009 tentang Kekuasaan Kehakiman (UU Kekuasaan Kehakiman) yang menentukan bahwa "Hakim wajib menggali, mengikuti dan memahami nilai-nilai hukum dan rasa keadilan yang hidup di masyarakat", dan juga ketentuan Pasal 10 ayat (1) UU Kekuasaan Kehakiman yang menyatakan bahwa, "Pengadilan tidak boleh menolak untuk memeriksa, mengadili dan memutus suatu perkara yang diajukan dengan dalih bahwa hukum tidak ada atau kurang jelas, melainkan wajib untuk memeriksa atau mengadilinya". ${ }^{18}$

Terdapat beberapa aspek yang luput untuk dijadikan pertimbangan majelis hakim MA dalam pertimbangan yang telah dikeluarkan oleh MA, yakni sebagai berikut:

1) Bahwa sebenarnya dalam penjelasan Pasal 2 ayat (1) UU Tipikor 2001, frasa kata melawan hukum menganut dua ajaran yakni ajaran melawan hukum formil dan

15 Andi Hamzah, Asas-asas Hukum Pidana Di Indonesia \& Perkembangannya, Medan: Soft Media, 2012, hlm. 178.

${ }^{16}$ Eddy O.S. Hiariej, Prinsip-Prinsip Hukum Pidana, Yogyakarta: Cahaya Atma Pustaka, 2014, hlm. 203.

17 Ibid., hlm. 204.

18 Lilik Mulyadi, Bunga Rampai Hukum Pidana..., Op.cit., hlm. 27. 
materiil. Jika pada ajaran melawan hukum materiil tersebut dinyatakan tidak mengikat secara hukum berarti masih ada ajaran sifat melawan hukum formilnya. Apabila dalam mencocokan rumusan pasal terhadap tindak pidana tidak ditemukan rumusannya dalam undang-undang tersebut, maka berlakulah asas retroaktif yang terdapat dalam Pasal 1 ayat (2) KUHP yang menyatakan bahwa, "Jika undang-undang diubah, setelah perbuatan itu dilakukan, maka kepada tersangka dikenakan ketentuan yang lebih menguntungkan". ${ }^{19}$ Dengan demikian, tidak ada kekosongan hukum dalam penerapan dan pengenaan pidana terhadap tersangka ataupun pihak justiabelen karena asas retroaktif hukum pidana tersebut menjamin kepastian hukum dan perlindungan hak asasi manusia atau hak konstitusional rakyat Indonesia.

2) Bahwa mengenai doktrin Sen-Clair atau La doctrine du Sen-Clair hakim harus melakukan penemuan hukum berdasarkan Pasal 5 ayat (1) UU Kekuasaan Kehakiman. Mengenai hal ini, dipertimbangkan apa yang dikemukakan oleh Andi Hamzah yang mengatakan:

"Tetapi apakah ketentuan ini hanya berlaku bagi hukum perdata dan adat, tidak berlaku untuk hukum pidana karena nullum crimen sine lege stricta dalam Pasal 1 ayat (1) KUHP Undang-Undang Kekuasaan Kehakiman tersebut tidak mengatakan tidak berlaku kewajiban hakim untuk menggali hukum yang hidup bagi hukum pidana. Dunia modern tidak dapat lagi menerima secara ketat apa yang dikatakan oleh Montesquieu, bahwa hakim hanya menjadi corong undang-undang (qui pronoce les paroles de la loi). Hal itu tidak dapat diterima secara absolut". 20

Selain itu, MA telah dua kali melepaskan terdakwa dari tuntutan hukum dalam perkara korupsi karena dipandang tidak melawan hukum secara materiil. Dalam pertimbangan MA, korupsi tersebut dilakukan demi kepentingan umum, negara tidak dirugikan, dan terdakwa tidak mendapat untung (Kasus Machrus Effendi 1966 dan Ir. Otjo Danuatmadja 1977). ${ }^{21}$ Di sisi lain, hakim perdata lebih bebas dalam menafsirkan perundang-undangan dalam hukum perdata daripada hakim pidana. Bahkan dalam hukum perdata dikenal analogi dan penafsiran penghalusan hukum (rechstverfijning) serta penafsiran a contrario. ${ }^{22}$ Dengan demikian, asas legalitas dalam hukum pidana menjadikan adanya pelarangan penggunaan analogi dalam pemidanaan.

19 Dina Novita Sari, "Pergeseran Ajaran Melawan Hukum Materiil Dalam Tindak Pidana Korupsi Sejak Berlakunya Undang-Undang No. 24 Tahun 1960 Hingga Undang-Undang No. 20 Tahun 2001 jo. Undang-Undang No 31 Tahun 1999", Skripsi Fakultas Hukum Universitas Indonesia, Jakarta, 2012, hIm. 161.

${ }^{20}$ Andi Hamzah, Asas-asas Hukum Pidana..., Op.cit., hlm. 108.

21 Ibid., hlm. 109.

22 Ibid. 
3) Bahwa hakim pidana tidak dapat membuat suatu norma untuk pemidanaan. Hal tersebut karena adanya teori pemisahan kekuasaan antara legislatif dengan yudikatif sehingga hanya kekuasaan legislatif yang berwenang menetapkan apakah suatu perbuatan dapat dipidana (kriminalisasi) baik melalui undangundang atau pembentukan norma dalam menentukan dekriminalisasi. Hal itu juga dikemukakan oleh Komariah Emong Sapradjaja bahwa hakim pidana tidak akan menginjakkan kakinya pada daerah kekuasaan pembuat undang-undang, sebab dengan menerapkan ajaran sifat melawan hukum materiil secara positif hakim pidana telah menambahkan unsur-unsur baru dalam rumusan delik, yang sesungguhnya hanya dapat dilakukan oleh pembuat undang-undang. Dengan memperhatikan kepentingan hukum yang hendak dilindungi oleh pembuat undang-undang, kepastian hukum akan tetap terjamin. Dengan demikian fungsi dan peranan asas legalitas lebih dipertajam. ${ }^{23}$

Korupsi memang merupakan kejahatan yang dikategorikan sebagai tindak pidana yang luar biasa (extraordinary crimes) yang penanggulangannya secara yuridis juga harus luar biasa (extraordinary enforcement), mengikuti aturan-aturan dan atau sistem hukum yang ada dan berlaku. Apabila ditinjau dari segi tatanan undang-undang di Indonesia sebelum ada putusan MK, dapat dikatakan bahwa penerapan ajaran sifat melawan hukum materiil dalam fungsi positif yang terdapat dalam Penjelasan Pasal 2 ayat (1) UU Tipikor 2001 merupakan kekhususan karena merupakan lex specialis dari suatu undang-undang dalam ranah hukum pidana. Tetapi pasca adanya putusan judicial review MK maka dalil kekhususan dan asas lex specialist tersebut tidaklah relevan, karena telah dinyatakan tidak memiliki kekuatan hukum mengikat sehingga tetap tunduk pada asas legalias hukum pidana tersebut.

Dengan demikian, penerapan ajaran sifat melawan hukum materiil dalam fungsi positif oleh MA pasca putusan judicial review oleh MK tersebut telah bertentangan dengan UUD 1945 Pasal 28 ayat (1) huruf D, asas legalitas, asas retroaktif, serta asas pemisahan kekuasaan negara. Selain itu, penerapan oleh MA tersebut tidak mengindahkan sudut hierarki peraturan perundang-undangan di Indonesia sehingga tidak mencerminkan kepastian hukum.

\section{Kajian Wewenang MA untuk Menerapkan Kembali Ajaran Sifat Melawan Hukum Materiil Fungsi Positif Pasca Putusan MK}

MA melalui lembaga peradilan yang berada di bawahnya sebagai lembaga yudikatif dalam melaksanakan kekuasaan kehakiman berdasarkan undang-undang yang berlaku dan lebih merupakan pengadilan keadilan (court of justice). Berbeda

${ }^{23}$ Komariah Emong Sapardjaja, Op.cit., hlm. 217. 
dengan MK yang merupakan lembaga yudikatif sebagai lembaga pengadilan hukum (court of law) yang tentunya memiliki kewenangan dan fungsi yang berbeda. Meskipun begitu, MA dan MK tetap saling berkaitan khususnya dalam pemberlakuan peraturan perundang-undangan yang berlaku, terlebih lagi dalam penegakan hukum di Indonesia. Untuk mengetahui berwenang atau tidaknya MA dalam menerapkan ajaran sifat melawan hukum dalam fungsi positif pasca putusan judicial review MK, maka hendaknya melihat terlebih dahulu fungsi dan kewenangannya. Selain itu, perlu diperhatikan pula sifat-sifat putusan antara putusan MA dengan MK.

Berdasarkan Undang-Undang Nomor 14 Tahun 1985 tentang Mahkamah Agung (UU MA 1985), MA selaku salah satu lembaga peradilan tertinggi memiliki fungsi mengatur yang lebih merupakan pengadilan keadilan, sebagaimana diatur dalam Pasal 79 UU MA 1985 dan juga telah diatur dalam Pasal 27 Undang-Undang Nomor 14 Tahun 1970 tentang Ketentuan-Ketentuan Pokok Kekuasaan Kehakiman (UU Kekuasaan Kehakiman 1970) yakni:

"Mahkamah Agung dapat mengatur lebih lanjut hal-hal yang diperlukan bagi kelancaran penyelenggaraan peradilan apabila terdapat hal-hal yang belum cukup diatur dalam Undang-Undang tentang Mahkamah Agung sebagai pelengkap untuk mengisi kekurangan atau kekosongan hukum yang diperlukan bagi kelancaran penyelenggaraan peradilan."

Dapat disimpulkan bahwa MA juga dapat melakukan penemuan hukum untuk mengisi kekosongan hukum tetapi tidak dijelaskan dalam bentuk produk hukum yang seperti apa dan bagaimana kekuatan hukumnya dalam hierarki perundangundangan yang ada di Indonesia.

Untuk melihat produk-produk hukum, MA harus melihat bagaimana peraturan perundang-undangan mengatur dan memberi kewenangan kepada MA. Pasal 24A UUD 1945 mengatur bahwa MA berwenang mengadili pada tingkat kasasi, menguji peraturan perundang-undangan di bawah undang-undang terhadap undangundang, dan mempunyai wewenang lainnya yang diberikan undang-undang. Hal ini juga sejalan dengan pandangan bahwa peraturan perundang-undangan hanya dapat dibentuk oleh lembaga-lembaga yang memperoleh kewenangan perundangundangan (wetgevingsbevoegheid), yaitu kekuasaan untuk membentuk hukum atau rechtsvormig. ${ }^{24}$

Pada umumnya, MA melakukan penemuan hukum untuk mengisi kekosongan hukum, baik melalui yurisprudensi tetap, maupun melalui Peraturan Mahkamah Agung (Perma) atau Surat Edaran Mahkamah Agung (SEMA) sebagai acuan hakim dalam mengadili suatu sengketa yang dianggap belum ada kaidah hukumnya.

\footnotetext{
${ }^{24}$ Maria Farida, Ilmu Perundang-Undangan, Yogyakarta: Kanisius, 1998, hlm. 54.
} 
Mengenai yurisprudensi, perlu diperhatikan bahwa sistem hukum Indonesia menurut Achmad Ali dapat diklasifikasikan sebagai mix legal system. ${ }^{25}$ Tetapi pada kenyataan, dalam praktik di peradilan, kekuatan yurisprudensi tetap pun tidak selalu menjadi acuan hakim dalam menjatuhkan suatu vonis dalam peradilan pidana, walaupun memang yurisprudensi telah digunakan pada kasus yang mirip. Hal tersebut terlihat pada MA yang pernah menerapkan ajaran sifat melawan hukum materiil dalam fungsi negatif, namun juga menerapkan ajaran sifat melawan hukum materiil dalam fungsi positif. Selain itu, putusan peradilan bisa saja hanya mengikat para pihak yang berperkara.

Apabila mengisi kekosongan hukum dalam memeriksa dan memutus perkara melalui Perma, maka perlu juga dilihat bagaimana kedudukan dan sifat dari Perma tersebut, yakni bentuk peraturan yang berisi ketentuan bersifat hukum acara. Sedangkan SEMA merupakan bentuk edaran Pimpinan MA ke seluruh jajaran peradilan yang berisi bimbingan dalam penyelenggaraan peradilan yang lebih bersifat administratif. Untuk mengetahui keabsahannya, maka perlu dilihat berdasarkan Undang-Undang Nomor 12 Tahun 2011 tentang Pembentukan Peraturan Perundang-undangan (UU 12/2011) yakni pada Pasal 8 ayat (1) dinyatakan bahwa, "Jenis peraturan perundang-undangan selain yang disebut dalam Pasal 7 ayat (1) mencakup peraturan yang ditetapkan ... Mahkamah Agung ...". Rumusan ini sama dengan dengan Pasal 7 ayat (4) dan Penjelasan UndangUndang Nomor 10 Tahun 2004 tentang Pembentukan Peraturan Perundangundangan (UU 10/2004).

Selanjutnya, pada Pasal 8 ayat (2) UU 12/2011 menegaskan bahwa peraturan perundang-undangan tersebut diakui keberadaannya dan mempunyai kekuatan hukum mengikat sepanjang diperintahkan oleh peraturan perundang-undangan yang lebih tinggi atau dibentuk berdasarkan kewenangan. Frasa kekuatan hukum adalah sesuai dengan hierarki peraturan perundang-undangan, yaitu jenjang setiap jenis peraturan perundang-undangan yang didasarkan pada asas bahwa peraturan perundang-undangan yang lebih rendah tidak boleh bertentangan dengan peraturan perundang-undangan yang lebih tinggi. Jenis peraturan lain, atau dalam konteks ini peraturan yang diterbitkan MA, seharusnya juga tunduk pada prinsip hierarki. Perihal penerapan produk hukum MA di peradilan, dapat dilihat dalam Pasal 32 ayat (4) UU MA 1985, yang frasa semua lingkungan peradilan sehingga dapat dikaitkan dengan fungsi pengawasan MA terhadap peradilan umum, peradilan agama, peradilan tata usaha negara, dan peradilan militer. Ukuran yang digunakan undang-undang adalah jangan sampai produk hukum tersebut

${ }^{25}$ Achmad Ali, Menguak Teori Hukum (Legal Theory) dan Teori Peradilan (Judicial prudence) Termasuk Interpretasi Undang-Undang (Legisprudence), Jakarta: Kencana Prenada Media Grup, 2009, hlm. 499. 
mengurangi kebebasan hakim dalam memeriksa dan memutus perkara. ${ }^{26}$ Dengan demikian, apabila ditinjau dari segi hierarki dalam perundang-undangan yang berlaku di Indonesia, maka baik yurisprudensi maupun Perma yang digunakan sebagai dasar hukum oleh MA dalam memeriksa suatu perkara dapat dikesampingkan oleh peraturan atau putusan yang lebih tinggi.

Di sisi lain, Pasal 24C UUD 1945 menegaskan bahwa MK berwenang mengadili pada tingkat pertama dan tingkat terakhir yang putusannya bersifat final untuk menguji undang-undang terhadap UUD 1945 (judicial review); memutus sengketa kewenangan lembaga negara yang kewenangannya diberikan oleh UUD 1945; memutus pembubaran partai politik; dan memutus perselisihan hasil pemilihan umum. Selain itu, MK pun wajib memberikan putusan atas pendapat Dewan Perwakilan Rakyat (DPR) mengenai dugaan pelanggaran oleh presiden dan atau wakil presiden menurut UUD 1945. Perihal kewenangan untuk melakukan judicial review, secara nyata UUD 1945 juga memberikan kewenangan tersebut kepada MA namun dengan tingkat pengajuan yang berbeda dengan kewenangan MK. MA berwenang melakukan judicial review yang dilakukan oleh MA yakni pengujian peraturan di bawah undang-undang terhadap undang-undang.

Melihat perbedaan kedua lembaga yang melaksanakan kekuasaan kehakiman tersebut, jelas terlihat bahwa tingkat pengujian judicial review oleh MK lebih tinggi daripada MA, sehingga hal ini dapat menimbulkan dampak yang signifikan terhadap pelaksanaan undang-undang secara nyata, karena pada Pasal 24C ayat (1) UUD 1945 menyatakan bahwa putusan MK bersifat final. Hal tersebut menjelaskan bahwa putusan MK telah memiliki kekuatan hukum tetap sejak dibacakan dalam persidangan MK dan suatu putusan pengadilan yang telah memiliki kekuatan hukum tetap memiliki kekuatan hukum mengikat untuk dilaksanakan.

Perbedaan yang paling terlihat yakni pada kekuatan mengikat putusan antara putusan MK dengan putusan MA. Kekuatan mengikat putusan MA hanya sebatas kepada pihak-pihak yang berperkara saja, sedangkan putusan MK selain mengikat para pihak yang berperkara, juga semua elemen negara baik itu rakyat dan lembaga tinggi negara. Hal ini juga dikemukakan oleh Muchammad Ali Safa'at yang menyatakan, bahwa putusan pengadilan biasa yang hanya mengikat para pihak, namun putusan MK dalam perkara pengujian undang-undang mengikat semua komponen bangsa, baik penyelenggara negara maupun warga negara ${ }^{27}$ atau yang dikenal dengan asas erga omnes.

Putusan MK tidak dapat dilepaskan dari asas erga omnes yang memiliki kekuatan mengikat secara hukum terhadap seluruh komponen bangsa, sehingga

\footnotetext{
${ }^{26}$ Muhammad Yasin, "Kekuatan Hukum Produk-Produk Hukum Mahkamah Agung”, , diakses 23 Desember 2014.

27 Muchamad Ali Safa'at, "Kekuatan Mengikat Dan Pelaksanaan Putusan MK", Makalah untuk Universitas Brawijaya Malang, tanpa tahun, hlm 2, Muchamad Ali Safa'at, "Penafsiran Konstitusi", http://safaat.lecture.ub.ac.id/2011/11/penafsiran-konstitusi/, diakses 5 Mei 2015.
} 
semua pihak harus tunduk dan taat melaksanakan putusan tersebut. ${ }^{28}$ Dalam perkara pengujian undang-undang, yang diuji adalah norma undang-undang yang bersifat abstrak dan mengikat umum. Walaupun dasar permohonan pengujian adalah adanya hak konstitusional pemohon yang dirugikan, namun sesungguhnya tindakan tersebut mewakili kepentingan hukum seluruh masyarakat, yaitu tegaknya konstitusi. ${ }^{29}$ Dengan demikian, MA selaku lembaga negara juga sepatutnya mematuhi dan melaksanakan putusan judicial review MA tersebut. Bahkan jika menggunakan kaidah yurisprudensi atau Perma sekalipun tetap saja tidak memiliki wewenang karena sebagaimana telah dijelaskan, bahwa kedudukan putusan MK lebih kuat dari segi mengikat dan kedudukannya dari putusan MA sebagai kaidah dalam perundang-undangan yang memberikan kewenangan dan kekuatan terhadap putusan judicial review MK, hal ini di dasarkan pada Pasal 24 huruf C UUD 1945 dan Pasal 10 ayat (1) huruf a Undang-Undang Nomor 24 Tahun 2003 tentang Mahkamah Konstitusi (UU MK 2003) menyatakan, "Mahkamah Konstitusi berwenang mengadili pada tingkat pertama dan terakhir yang putusannya bersifat final untuk menguji Undang-Undang terhadap UUD 1945".

Dengan putusan judicial review MK terhadap penjelasan Pasal 2 ayat (1) UU Tipikor 2001 menyebabkan frasa "melawan hukum materiil" menjadi tidak mengikat dan berlaku sehingga seharusnya menjadi pertimbangan putusan MA terhadap terdakwa bebas atau lepas dari segala tuntutan karena hilangnya sifat melawan hukumnya.

Apabila MA tidak mematuhi putusan judicial review MK, maka majelis hakim MA yang menerapkan ajaran melawan hukum materiil dalam fungsi positif dapat dinyatakan telah melanggar hukum. Hal tersebut sesuai dengan yang dikemukakan oleh Maruarar Siahaan yang menyatakan bahwa satu tindakan yang pengawasannya ada dalam suatu mekanisme hukum tata negara dan selanjutnya perbuatan yang dilakukan atas dasar undang-undang yang sudah dinyatakan batal dan tidak mempunyai kekuatan hukum mengikat merupakan perbuatan melawan hukum. Jika konsekuensi atau akibat hukum yang terjadi berupa kerugian finansial, aparat negara atau lembaga negara tersebut akan menanggung akibat hukum yang dapat bersifat pribadi (personal liability) untuk mengganti kerugian yang dituntut melalui peradilan biasa yang dapat ditegakkan secara paksa. ${ }^{30}$ Sebagai contoh, dasar hukum yang dapat digunakan jika ada apartur negara menggunakan pasal

\footnotetext{
${ }^{28}$ Syukri Asy'ari, Meyrinda Rahmawaty Hilipito, dan Mohammad Mahrus Ali, Model dan Implementasi Putusan Mahkamah Konstitusi Dalam Pengujian Undang-Undang (Studi Putusan Tahun 2003-2012), Jakarta: Pusat Penelitian dan Pengkajian Perkara Pengelolaan Teknologi Informasi Dan Komunikasi Kepaniteraan dan Sekertariat Jenderal Mahkamah Konstitusi RI, 2012.

${ }^{29}$ Muchamad Ali Safa'at, Op.cit., hlm. 2.

${ }^{30}$ Iriyanto A. Baso Ence, Negara Hukum \& Hak Uji Konstitusionalitas Mahkamah Konstitusi (Telaah Terhadap Kewenangan Mahkamah Konstitusi), Bandung: Alumni, 2008, hlm. 201.
} 
yang sudah tidak berlaku atau tidak mengikat secara hukum yang secara jelas merugikan secara finansial, maka dapat digunakan kaidah Pasal 1365 Kitab UndangUndang Hukum Perdata (KUHPerdata) dan langkah hukum lainnya.

Maruarar Siahaan juga mengemukakan model putusan yang secara hukum membatalkan dan menyatakan tidak berlaku. Terlihat dalam putusan MK terhadap permohonan yang beralasan untuk dikabulkan, sebagaimana ditentukan dalam Pasal 56 ayat (3) dan Pasal 57 ayat (1) UU MK 2003. Di dalam model putusan ini, MK sekaligus menyatakan bahwa suatu undang-undang yang diuji bertentangan dengan UUD 1945 baik seluruhya maupun sebagian dan pernyataan bahwa yang telah dinyatakan bertentangan tersebut tidak mempunyai kekuatan hukum mengikat sejak selesai diucapkan dalam sidang pleno yang terbuka untuk umum. Dalam hal ini, MK tidak membuat norma baru ${ }^{31}$ karena hanya sebagai negative legislator, seperti yang disebut oleh Hans Kelsen adalah melalui suatu pernyataan atau deklaratif.

Sifat putusan deklaratif tidak membutuhkan satu aparat khusus untuk melaksanakan putusan. Namun demikian, sebagai syarat untuk diketahui secara umum, putusan demikian diumumkan dalam berita negara dalam jangka waktu paling lambat tiga puluh hari sejak putusan diucapkan. Dengan dimuat dalam berita negara, maka seluruh penyelenggara negara dan warga negara terikat untuk tidak menerapkan dan melaksanakan lagi norma hukum yang telah dinyatakan inkonstitusional dan tidak mempunyai kekuatan hukum mengikat oleh MK. Oleh karena itu, jika terdapat suatu perbuatan yang dilakukan atas dasar undang-undang yang sudah dinyatakan oleh MK, baik seluruhnya maupun sebagian, bertentangan dengan UUD 1945 dan tidak mempunyai kekuatan hukum mengikat, maka perbuatan tersebut dapat dikualifikasi sebagai perbuatan melawan hukum dan batal demi hukum sejak semula (ab initio). ${ }^{32}$

Apabila sekilas dibandingkan dengan putusan MK Italia, satu undang-undang hukum pidana dinyatakan inskonstitusional dan tidak mempunyai kekuatan hukum mengikat, sehingga sejak awal undang-undang tersebut tidak berlaku (void ab initio). Semua putusan yang menghukum terdakwa atas dasar undang-undang hukum pidana demikian menjadi batal dan dengan sendirinya menyebabkan terdakwa harus dibebaskan. Bahkan, hukuman yang telah dijalani berdasarkan undang-undang yang dinyatakan batal itu juga dinyatakan tidak berlaku. ${ }^{33}$

31 Maruarar Siahaan, "Peran Makamah Konstitusi Dalam Penegakan Hukum Konstitusi”, Jurnal Hukum, No.3 Vol. 16, Juli 2009, hlm. 358.

32 Ibid., hlm. 251-252.

33 Iriyanto A. Baso Ence, Op.cit., hlm. 204. 


\section{Penutup}

Berdasarkan pembahasan di atas, maka disimpulkan beberapa hal. Pertama, MA telah bertindak melewati kewenangannya dan tidak berwenang menerapkan kembali ajaran sifat melawan hukum materiil dalam fungsi positif karena dasar hukumnya telah dinyatakan tidak memiliki kekuatan hukum mengikat oleh MK. Selain itu, mengingat proses judicial review dengan penerapan hukum pidana positif terhadap Pasal 2 ayat (1) UU Tipikor 2001 sebagai satu kesatuan sistem hukum, MA tentu saja seharusnya menjadikan putusan MK sebagai pertimbangan hukum memeriksa dan memutus perkara, karena peraturan yang diuji memang dibuat untuk menindaklanjuti putusan MK. Hakim MA tentu paham benar mengenai kedudukan putusan MK sebagai negative legislation.

Kedua, penerapan ajaran sifat melawan hukum positif oleh MA pasca putusan MK juga melanggar hak konstitusional terdakwa. Walaupun demikian, penegakan hukum korupsi masih dapat dilaksanakan dengan menggunakan jalur perdata karena pengembalian aset yang telah diambil oleh para koruptor masih dapat dilakukan upaya perdata sebagaimana yang diatur dalam Pasal 32 ayat (1) dan (2) UU Tipikor 2001. Maka dari itu, pemberantasan tindak pidana korupsi memerlukan instrumen hukum terpadu antara segi hukum pidana, hukum administrasi, serta ranah hukum perdata baik secara horizontal maupun vertikal. Selain itu, pemberantasan tindak pidana korupsi itu juga perlu didukung oleh kualitas perundang-undangan yang baik agar pelaksanaannya pun dapat berjalan dengan terpadu, harmonis, dan dapat mencerminkan kepastian hukum, keadilan, serta kemanfaatan.

Ketiga, penerapan ajaran sifat melawan hukum materiil dalam fungsi positif oleh MA pasca putusan MK telah bertentangan dengan UUD 1945 Pasal 28 ayat (1) huruf $D$ dan asas legalitas serta asas pemisahan kekuasaan negara. Keempat, MA tidak menaati sudut hierarki peraturan perundang-undangan di Indonesia, sehingga tidak mencerminkan adanya fungsi kepastian hukum. MA tidak berwenang untuk menerapkan kembali ajaran sifat melawan hukum dalam fungsi positif yang terdapat dalam undang-undang tindak pidana korupsi dikarenakan MK telah memutuskan bahwa ajaran tersebut tidak memiliki kekuatan hukum mengikat. Putusan judicial review MK itu tersendiri selain mengikat para pihak yang berperkara juga mengikat semua elemen negara, baik itu rakyat maupun lembaga tinggi negara sehingga seharusnya MA juga melaksanakan dan mematuhi putusan judicial review tersebut mengingat kedudukan putusan MK sebagai negative legislation. 


\section{Daftar Pustaka}

\section{Buku}

Achmad Ali, Menguak Teori Hukum (Legal Theory) dan Teori Peradilan (Judicialprudence) Termasuk Interpretasi Undang-Undang (Legisprudence), Kencana Prenada Media Grup, Jakarta, 2009.

Andi Hamzah, Asas-asas Hukum Pidana Di Indonesia \& Perkembangannya, Soft Media, Medan, 2012.

Chaerudin, Syaiful Ahmad Dinar, Syarif Fadilla, Strategi Pencegahan \& Penegakan Hukum Tindak Pidana Korupsi, Refika Aditama, Bandung, 2008.

Eddy O.S. Hiariej, Prinsip-Prinsip Hukum Pidana, Cahaya Atma Pustaka, Yogyakarta, 2014.

Jakarta, 2009.

Elwi Danil, Korupsi, Konsep, Tindak Pidana, Dan Pemberantasannya, Rajawali Press, Jakarta, 2011.

Iriyanto A. Baso Ence, Negara Hukum \& Hak Uji Konstitusionalitas Mahkamah Konstitusi (Telaah Terhadap Kewenangan Mahkamah Konstitusi), Alumni, Bandung, 2008.

Jonker Sihombing, Tanggung Jawab Yuridis Bankir Atas Kredit Macet Nasabah, Alumni, Bandung, 2009.

Komariah Emong Sapardjaja, Ajaran Sifat Melawan Hukum Materiil Dalam Hukum Pidana Indonesia (Studi Kasus Tentang Penerapan dan Perkembangannya dalam Yurisprudensi), Alumni, Bandung, 2002.

Lilik Mulyadi, Tindak Pidana Korupsi Di Indonesia, Normatif, Teoretis, Praktik dan Masalahnya Alumni, Bandung, 2007.

2012.

Maria Farida, Ilmu Perundang-Undangan, Kanisius, Yogyakarta, 1998.

MoeljatnoAsas Asas Hukum Pidana, Bina Aksara, Jakarta, 1987.

Muladi dan Barda Nawawi Arief, Teori-Teori dan Kebijakan Hukum Pidana, Alumni, Bandung, 2010.

Ni'matul Huda, Hukum Tata Negara Indonesia, Rajawali Press, Jakarta, 2007.

Nyoman Sarikat Putra Jaya, Beberapa Pemikiran Ke Arah Pengembangan Hukum Pidana, Citra Adiya Bakti, Bandung, 2008.

Syukri Asy'ari, Meyrinda Rahmawaty Hilipito, Mohammad Mahrus Ali, Model dan Implementasi Putusan Mahkamah Konstitusi Dalam Pengujian Undang-Undang (Studi Putusan Tahun 2003-2012), Pusat Penelitian dan Pengkajian Perkara Pengelolaan Teknologi Informasi Dan Komunikasi Kepaniteraan dan Sekertariat Jenderal Mahkamah Konstitusi RI, Jakarta, 2012 


\section{Dokumen Lain}

Dina Novita Sari, “Pergeseran Ajaran Melawan Hukum Materiil Dalam Tindak Pidana Korupsi Sejak Berlakunya Undang-Undang Nomor 24 Tahun 1960 Hingga Undang-Undang Nomor 20 Tahun 2001 Jo. Undang-Undang Nomor 31 Tahun 1999", Skripsi Fakultas Hukum Universitas Indonesia, Jakarta, 2012.

Maruarar Siahaan, "Peran Makamah Konstitusi Dalam Penegakan Hukum Konstitusi", Jurnal Hukum, No. 3 Vol. 16, Juli 2009.

Mompang L. Pangabean, "Kebijakan Legislatif Dalam Hukum Pelaksanaan Pidana Di Indonesia", Masalah-Masalah Hukum, Jilid 41, No. 2, April 2012.

Muchamad Ali Safa'at, "Kekuatan Mengikat Dan Pelaksanaan Putusan MK", Makalah untuk Universitas Brawijaya Malang, tanpa tahun "Penafsiran Konstitusi", http://safaat.lecture.ub.ac.id/2011/11/ penafsiran-konstitusi/, diakses 5 Mei 2015.

Muhammad Yasin, "Kekuatan Hukum Produk-Produk Hukum Mahkamah Agung", , diakses 23 Desember 2014.

\section{Dokumen Hukum}

Undang-Undang Dasar 1945.

Undang-Undang Nomor 20 Tahun 2001 tentang Perubahan Atas Undang-Undang Nomor 31 Tahun 1999 tentang Pemberantasan Tindak Pidana Korupsi. Undang-Undang Nomor 48 Tahun 2009 tentang Kekuasaan Kehakiman. Kitab Undang-Undang Hukum Pidana. 